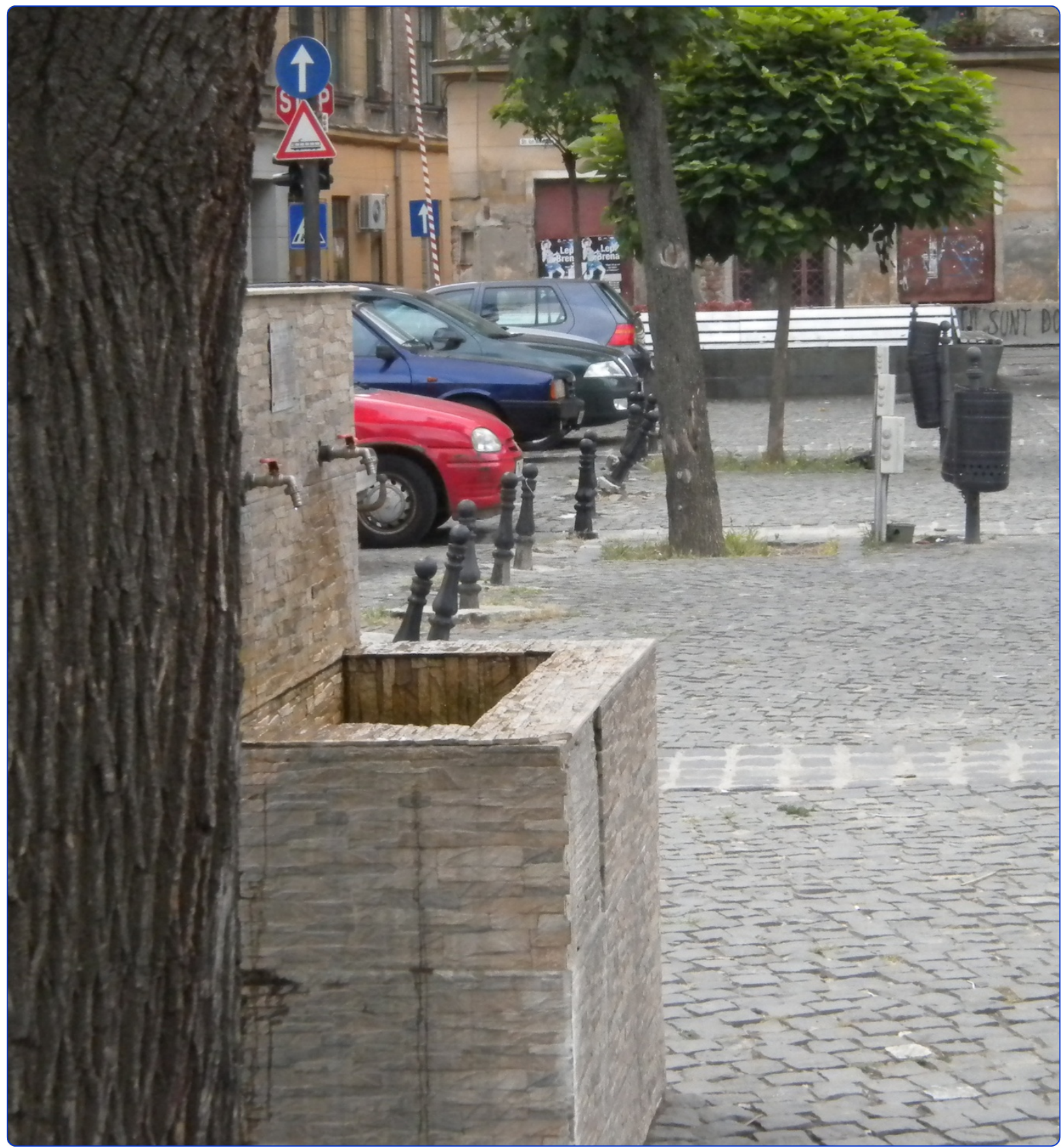

Consumption of low-moderate level arsenic contaminated water does not increase spontaneous pregnancy loss: a case control study

Bloom et al. 


\title{
Consumption of low-moderate level arsenic contaminated water does not increase spontaneous pregnancy loss: a case control study
}

Michael S Bloom ${ }^{1,2^{*}}$, Iulia A Neamtiu ${ }^{3}$, Simona Surdu' ${ }^{1}$ Cristian Pop ${ }^{3}$, Ioana Rodica Lupsa ${ }^{3}$, Doru Anastasiu, ${ }^{4,5}$, Edward F Fitzgerald ${ }^{1,2}$ and Eugen S Gurzau ${ }^{3,6}$

\begin{abstract}
Background: Previous work suggests an increased risk for spontaneous pregnancy loss linked to high levels of inorganic arsenic (iAs) in drinking water sources $(>10 \mu \mathrm{g} / \mathrm{L})$. However, there has been little focus to date on the impact of low-moderate levels of iAs in drinking water $(<10 \mu \mathrm{g} / \mathrm{L})$. To address this data gap we conducted a hospital-based case-control study in Timis County, Romania.

Methods: We recruited women with incident spontaneous pregnancy loss of 5-20 weeks completed gestation as cases $(n=150)$, and women with ongoing pregnancies matched by gestational age ( \pm 1 week) as controls $(n=150)$. Participants completed a physician-administered questionnaire and we collected water samples from residential drinking sources. We reconstructed residential drinking water exposure histories using questionnaire data weighted by iAs determined using hydride generation-atomic absorption spectrometry (HG-AAS). Logistic regression models were used to generate odds ratios (OR) and 95\% confidence intervals (Cl) for associations between iAs exposure and loss, conditioned on gestational age and adjusted for maternal age, cigarette smoking, education and prenatal vitamin use. We explored potential interactions in a second set of models.

Results: Drinking water arsenic concentrations ranged from 0.0 to $175.1 \mu \mathrm{g} / \mathrm{L}$, with median $0.4 \mu \mathrm{g} / \mathrm{L}$ and $90^{\text {th }} \%$ tile $9.4 \mathrm{\mu g} / \mathrm{L}$. There were no statistically significant associations between loss and average or peak drinking water iAs concentrations (OR 0.98, 95\% Cl 0.96-1.01), or for daily iAs intake (OR 1.00, 95\% Cl 0.98-1.02). We detected modest evidence for an interaction between average iAs concentration and cigarette smoking during pregnancy $(P=0.057)$ and for daily iAs exposure and prenatal vitamin use $(P=0.085)$.

Conclusions: These results suggest no increased risk for spontaneous pregnancy loss in association with low to moderate level drinking water iAs exposure. Though imprecise, our data also raise the possibility for increased risk among cigarette smokers. Given the low exposures overall, these data should reassure pregnant women and policy makers with regard to the potential effect of drinking water iAs on early pregnancy, though a larger more definitive study to investigate the potential risk increase in conjunction with cigarette smoking is merited.
\end{abstract}

Keywords: Arsenic, Cigarette smoking, Drinking water, Human reproduction, Pregnancy loss, Spontaneous abortion

\footnotetext{
* Correspondence: mbloom@albany.edu

'Department of Environmental Health Sciences, University at Albany, State

University of New York, School of Public Health, Rensselaer, NY, USA

${ }^{2}$ Department of Epidemiology and Biostatistics, University at Albany, State

University of New York, School of Public Health, Rensselaer, NY, USA

Full list of author information is available at the end of the article
} 


\section{Background}

The consumption of contaminated groundwater is the primary source of human exposure to inorganic arsenic (iAs), a highly toxic metalloid present naturally in the earth's crust [1]. Worldwide, reports describe contamination of drinking water sources ranging from less than $0.5 \mu \mathrm{g} / \mathrm{L}$ to more than $5,000 \mu \mathrm{g} / \mathrm{L}[2,3]$. Adverse human health effects, including increased rates of spontaneous clinical pregnancy loss have been reported in so-called 'arsenic endemic' areas, regions where drinking water iAs contamination exceeds $10 \mu \mathrm{g} / \mathrm{L}$ and frequently $50 \mu \mathrm{g} / \mathrm{L}[4,5]$. The results of epidemiologic studies conducted among pregnant women residing in the iAs endemic regions of Hungary [6], Chile [7], Bangladesh [8-15], India [16-18] and Mongolia [19], demonstrate increases in the risk of loss in association with drinking water iAs exposure $>10 \mu \mathrm{g} / \mathrm{L}$.

Despite the evidence from arsenic-endemic regions there are very few data available to characterize the dose-response relation between low-moderate drinking water iAs contamination and adverse human health effects [20]. Little information is available to assess risks in the low-moderate range, that is, concentrations below $10 \mu \mathrm{g} / \mathrm{L}$, to which a large population is exposed globally $[2,21]$. Only a single epidemiologic study has been reported in which pregnancy loss was assessed in association with low-moderate drinking water iAs exposures; a $50 \%$ increase in odds for pregnancy loss was reported for concentrations as low as $0.8-1.3 \mu \mathrm{g} / \mathrm{L}$, albeit not of statistical significance [22]. Given the widespread nature of low-moderate drinking water iAs contamination and a $12-14 \%$ baseline incidence of spontaneous clinical pregnancy loss in humans [23,24], even a modest increase in risk will attribute a large number of events and thus comprise a substantial public health burden. There is a critical need for epidemiologic studies to assess and quantify the risk and to help guide prevention efforts. As an initial step to help address this gap we conducted a pilot investigation in Timis County, Romania, an area known for low-moderate iAs contamination of drinking groundwater sources [25].

\section{Methods}

\section{Study sample}

We enrolled 150 incident cases of clinically-recognized spontaneous pregnancy loss prior to 20 weeks completed gestation as case participants, and 150 singleton pregnancies receiving prenatal care services as control participants, between December 2011 and January 2013. Prenatal care is provided at no cost and is compulsory in Romania, as is treatment for spontaneous loss. All new pregnancies are registered by family physicians, and referred to an obstetrician for evaluation and clinical examination within one month of gestation. Follow-up prenatal care visits are required in the $2^{\text {nd }}$ and $3^{\text {rd }}$ trimesters. Based on clinical experience, we estimate that $85 \%$ of pregnant women comply with the policy and receive pregnancy services; more than 99\% of women do so at no cost using county medical facilities. The majority of Timis County pregnancies are attended at the Obstetrics and Gynecology Department of the Emergency County Hospital (Bega Hospital), a comprehensive 1174 bed government medical facility located in the county capital city Timisoara and the site for our study. Women receiving prenatal care for ongoing pregnancies of similar duration to each case-participant ( \pm 1 week) were enrolled as controls. A nurse explained the study to women upon admission, obtained consent and completed a basic medical intake form as part of routine clinical evaluation. Participants were remunerated by $\$ 20.00$ U.S. equivalent in Romanian Lei. The study protocol was approved by the Institutional Review Boards of the County Emergency Hospital in Timisoara and the University at Albany, State University of New York. All participants provided informed consent prior to study enrollment.

After admission, participants completed a physicianadministered questionnaire concerning demographics, socioeconomic and lifestyle factors, as well as medical, gynecologic, and occupational histories that were validated during completion of the New York State Angler Cohort Study Prospective Pregnancy Study [26]. Additional questions regarding residential and workplace drinking water consumption history were validated during completion of the Arsenic Health Risk and Molecular Epidemiology (ASHRAM) study [27] We abstracted clinical data from basic medical intake forms completed by nursing staff, such as personal and family medical history, reproductive history and menstrual characteristics. Urine specimens, for a future speciated arsenic analysis, and blood specimens for future genetic and nutritional analyses were collected at the time of the interview, and archived at $-20 \mathrm{C}$.

\section{Water analysis}

Trained study staff collected drinking water samples onsite into $50 \mathrm{~mL}$ screw-top polyethylene containers previously decontaminated with nitric acid $\left(\mathrm{HNO}_{3}\right)$ and rinsed. Containers were twice partly filled with sample water $(\sim 33 \mathrm{~mL})$, tightly capped, shaken vigorously and emptied prior to collection to the upper edge of the container. We immediately added $100 \mu \mathrm{L}$ of concentrated analytical grade $\mathrm{HNO}_{3}$ as a preservative. Water samples were stored in a cooler with ice until delivery to the Environmental Health Center laboratory (Cluj-Napoca, Romania) for analysis. Sample water $(25 \mathrm{~mL})$ was mixed with $10 \mathrm{~mL} \mathrm{HCL}$ and $2 \mathrm{~mL}$ aqueous $5 \% \mathrm{KI}$ and $5 \%$ ascorbic acid $(\mathrm{m} / \mathrm{m})$. Samples were gently heated to $50^{\circ} \mathrm{C}$ for 15 minutes to reduce $\mathrm{As}^{5+}$ to $\mathrm{As}^{3+}$ and then cooled at room temperature. We transferred the sample to a volumetric flask with $50 \mathrm{~mL}$ nominal capacity and diluted to volume with de- 
ionized water. Hydrides were generated using $0.3 \% \mathrm{NaBH}_{4}$ dissolved in $0.1 \% \mathrm{NaOH}$ and $3 \% \mathrm{HCL}(\mathrm{m} / \mathrm{v})$, transported to a quartz cell heated to $960^{\circ} \mathrm{C}$ and analysed by a Zeenit 700p atomic absorption spectrometer (Analytikjena, Jena, Germany). We purchased reagents from Merck (Darmstadt, Germany), Sigma-Aldrich (Steinheim, Germany) and Chem Lab (Zedelgem, Belgium).

Arsenic calibration standard concentrations were 0.0, 1.0, 3.0, 7.0 and $10.0 \mu \mathrm{g} / \mathrm{L}$. Quality control (QC) was maintained using a second set of source calibration solutions prepared identically to the calibration standards. Measured values of prepared QC samples were within two standard deviations of the calibration standards (e.g., for the $5 \mu \mathrm{g} / \mathrm{L}$ QC sample a value between $4.67 \mu \mathrm{g} / \mathrm{L}$ and $5.33 \mu \mathrm{g} / \mathrm{L}$ was acceptable, given the standard deviation of 0.166 ). The method detection limit (MDL) was $0.5 \mu \mathrm{g} / \mathrm{L}$. For the purposes of reporting concentrations negative values were censored as zero, although no values were censored below the MDL during regression analysis to avoid the introduction of bias this may cause [28].

\section{Exposure indices}

Exposure was defined by three indices: 1) average iAs concentration $(\mu \mathrm{g} / \mathrm{L})$, comprising the mean levels measured in up to two residential drinking water sources; 2) peak iAs concentration $(\mu \mathrm{g} / \mathrm{L})$, the highest iAs level measured in up to two residential drinking water sources; and 3) daily exposure $(\mu \mathrm{g} /$ day), the product of average reported daily residential drinking water consumption from non-bottled sources (including teas, coffees, other water-mixed beverages and soups) during pregnancy multiplied by the average iAs concentration.

\section{Statistical analysis}

We examined distributions and evaluated bivariate associations among pregnancy loss, exposure indices and potential confounding factors. We generated logistic regression models, conditioned on gestational age, using iAs exposure indices as predictors, pregnancy loss as the outcome, and adjusted for confounders selected using literature evidence coupled to directed acyclic graphs (DAGs). DAGs employ causal graphing theory to allow identification of minimally sufficient covariates sets to control for confounding while minimizing bias [29]. We included age $[30,31]$ and smoking as continuous variables $[32,33]$, categorical education ( $<$ high school, high school, university) as a proxy for socioeconomic status [34-36], and self-reported use of perinatal vitamin supplements as a dichotomous variable $[37,38]$. The impact of body mass index (BMI), a continuous proxy for overall nutritional status, was assessed and defined as the weight divided by the square of height measured at the time of the study interview. We operationalized exposure indices as continuous predictors to maximize statistical power, and as tertiles of the control distribution to assess non-linear associations.

We also evaluated departures from multiplicativity by incorporating product terms between continuous exposures, expressed as a 10 units increase, and covariates $a$ priori specified as likely to modify iAs-pregnancy loss associations into additional regression models. These included age and BMI (pre-pregnancy and measured at the time of the interview) dichotomized at the median of the control distribution, urban vs. rural residence, education, smoking during pregnancy (no/yes), use of prenatal vitamins, and self-reported reproductive history, including previous pregnancy, live birth, and pregnancy loss (no/yes). We further scrutinized product terms significant by Wald test, and characterized the individual effects and joint effects relative to no exposure where these departed from multiplicativity [39].

For all models, we excluded influential observations, described as DfBeta $\geq|1.0|$ for either exposure or product terms, and repeated the analysis [40]. Under our incidence density case sampling strategy exponentiation of conditional logistic regression model coefficients and their corresponding 95\% confidence intervals (95\% CI) provided unbiased odds ratio (OR) estimates of the underlying population incidence rate ratio [41]. SAS v.9.3 (SAS Institute Inc., Cary, NC) was used for data analysis and statistical significance was defined as $\mathrm{P}<0.05$ for main effects and $\mathrm{P}<0.10$ for product terms. In keeping with the preliminary nature of our study, no adjustment was made for type-1 error inflation due to multiple-comparisons.

\section{Results}

\section{Univariate and bivariate analyses}

One-hundred seventy spontaneous pregnancy losses occurred at Bega Hospital over the study period, $88 \%$ of women with losses consented to participate in our study as cases; $83 \%$ of women approached with ongoing pregnancies agreed to participate as controls. As described by Table 1, cases and controls were approximately 8.0 and 8.5 weeks pregnant on average, respectively, with a range of 5.0-20.0 weeks. Cases were significantly older than controls and less likely to have reported use of prenatal vitamins. Pre-pregnancy BMI and BMI measured at the time of the interview were similar for cases and controls, although we detected modest increases between prepregnancy report and measured value at the time of the interview $(\delta=0.31 \mathrm{~kg}, \mathrm{P}=0.02$ and $\delta=0.45 \mathrm{~kg}, \mathrm{P}<0.0001$, respectively). Cases and controls were similar in terms of urban vs. rural residence, marital status and formal education. No differences were detected with respect to cigarette smoking and alcohol consumption during pregnancy. Cases reported significantly more prior pregnancies and live births than controls, although the number of prior losses (including elective terminations) was similar. 
Table 1 Study sample characteristics by case-control status

\begin{tabular}{|c|c|c|c|c|c|c|c|}
\hline \multirow[t]{2}{*}{ Factor } & \multicolumn{3}{|c|}{ Cases $(n=150)$} & \multicolumn{3}{|c|}{ Controls $(n=150)$} & \multirow[t]{2}{*}{ P-value } \\
\hline & $\mathrm{n}$ & Median, (\%) & Range & $\mathrm{n}$ & Median, (\%) & Range & \\
\hline \multicolumn{8}{|l|}{ Demographic: } \\
\hline Gestational age (weeks) & 150 & 8.0 & $5-20$ & 150 & 8.5 & $5-20$ & 0.256 \\
\hline Maternal age (years) & 150 & 30.0 & $18.0-42.3$ & 150 & 27.6 & $18.8-41.9$ & 0.029 \\
\hline BMI, pre-pregnancy $\left(\mathrm{kg} / \mathrm{m}^{2}\right)$ & 148 & 21.6 & $15.9-46.6$ & 148 & 21.8 & $15.1-36.7$ & 0.838 \\
\hline BMl, interview $\left(\mathrm{kg} / \mathrm{m}^{2}\right)$ & 148 & 22.1 & $15.9-46.6$ & 150 & 22.2 & $16.2-38.5$ & 0.702 \\
\hline Urban residence & 108 & $(72.0)$ & - & 98 & $(65.3)$ & - & 0.258 \\
\hline Married, living as married & 129 & $(86.0)$ & - & 120 & $(80.0)$ & - & 0.160 \\
\hline \multicolumn{8}{|l|}{ Education $^{\text {b }}$} \\
\hline University diploma & 60 & $(40.3)$ & - & 68 & $(45.3)$ & - & 0.652 \\
\hline High school diploma & 51 & $(34.2)$ & - & 45 & $(30.0)$ & - & - \\
\hline No high school diploma & 38 & $(25.5)$ & - & 37 & $(24.7)$ & - & - \\
\hline \multicolumn{8}{|l|}{ Health-related behaviors: } \\
\hline Prenatal vitamins during pregnancy & 67 & $(44.7)$ & - & 97 & $(64.7)$ & - & 0.0005 \\
\hline Smoked during pregnancy & 41 & $(27.3)$ & - & 36 & $(24.0)$ & - & 0.515 \\
\hline Average daily cigarettes $^{c}$ & 41 & 10 & $2-50$ & 36 & 10 & $1-20$ & 0.267 \\
\hline Alcohol during pregnancy & 12 & $(8.0)$ & - & 13 & $(8.7)$ & - & 0.842 \\
\hline Work stress during pregnancy & 63 & $(42.0)$ & - & 71 & $(47.3)$ & - & 0.339 \\
\hline Home stress during pregnancy & 62 & $(41.3)$ & - & 57 & $(38.0)$ & - & 0.522 \\
\hline \multicolumn{8}{|l|}{ Reproductive history: } \\
\hline Prior pregnancies & 150 & 1 & $0-14$ & 150 & 1 & $0-9$ & 0.038 \\
\hline Prior live births & 150 & 0 & $0-12$ & 150 & 0 & $0-3$ & 0.021 \\
\hline Prior losses & 150 & 0 & $0-7$ & 150 & 0 & $0-8$ & 0.378 \\
\hline
\end{tabular}

${ }^{a}$ Wilcoxon signed-rank test or McNemar's $x^{2}$-test for difference between cases $\&$ controls; ${ }^{b} n=1$ missing case value; ${ }^{c}$ Among $n=77$ smokers.

Distributions for iAs exposure metrics are described in Table 2. Although the range of water concentrations was large overall $(0-175.10 \mu \mathrm{g} / \mathrm{L}$ iAs), more than $90 \%$ of participants used water sources contaminated by less than $9.39 \mu \mathrm{g} / \mathrm{L}$ iAs, with a median average concentration of $0.41 \mu \mathrm{g} / \mathrm{L}$. Five participants $(\mathrm{n}=2$ cases, $\mathrm{n}=3$ controls) were exposed to residential water sources with iAs concentration in excess of $50 \mu \mathrm{g} / \mathrm{L}$ on average. In general, unadjusted concentrations were higher among controls than among cases, though differences were not significant. Cases reported significantly higher water consumption from residential sources than controls $(\delta=0.3 \mathrm{~L}, \mathrm{P}=0.002)$. Most women $(n=299)$ had resided in the study residence for at least one year (median $=5.5$, range $0.5-42$ ).

\section{Multivariable analyses}

We generated logistic regression models for each of three drinking water iAs indices as predictors, conditioned on gestational age, and adjusted for maternal age, cigarette smoking during pregnancy, education and prenatal vitamin use (Table 3). Data for two participants were excluded from the analysis due to influential observations. Effect

Table 2 Distribution of inorganic arsenic (iAs) exposure indices by case-control status

\begin{tabular}{|c|c|c|c|c|c|c|c|}
\hline \multirow[t]{2}{*}{ Factor } & \multicolumn{3}{|c|}{ Cases $(n=150)$} & \multicolumn{3}{|c|}{ Controls $(n=150)$} & \multirow[t]{2}{*}{ P-value } \\
\hline & Mean & Median & $\overline{\text { Range }}$ & Mean & Median & $\overline{\text { Range }}$ & \\
\hline Daily water consumption $(\mathrm{L})^{\mathrm{b}}$ & 1.49 & 1.50 & $0.5-5.0$ & 1.26 & 1.20 & $0.0-4.0$ & 0.002 \\
\hline Average iAs $(\mu \mathrm{g} / \mathrm{L})^{c}$ & 4.06 & 0.17 & $0-175.10$ & 4.32 & 1.28 & $0-130.30$ & 0.169 \\
\hline Peak iAs $(\mu \mathrm{g} / \mathrm{L})^{\mathrm{d}}$ & 4.64 & 0.17 & $0-175.10$ & 4.99 & 2.27 & $0-130.30$ & 0.121 \\
\hline Daily iAs $(\mu \mathrm{g} / \text { day })^{e}$ & 7.10 & 0.24 & $0-350.20$ & 5.16 & 1.45 & $0-83.15$ & 0.130 \\
\hline
\end{tabular}

Wilcoxon signed-rank test; ${ }^{\mathrm{b}}$ average water consumed from non-bottled sources, including direct consumption, teas, coffees, mixed beverages and soups; ${ }^{\mathrm{C}}$ mean iAs level measured in up to two residential drinking water sources; ${ }^{d}$ the highest iAs concentration measured in up to two residential drinking water sources; eproduct of 'daily water consumption' multiplied by 'average iAs.' 
Table 3 Covariate-adjusted odds ratios for spontaneous pregnancy loss in association with continuous iAs exposure $(n=300)$

\begin{tabular}{|c|c|c|}
\hline Predictor & $O^{a}$ & $95 \% \mathrm{Cl}$ \\
\hline Average iAs $(\mu \mathrm{g} / L)^{\mathrm{b}, \mathrm{c}}$ & 0.98 & $0.96,1.01$ \\
\hline Age & 1.05 & $1.00,1.10$ \\
\hline Smoking & 1.02 & $0.98,1.06$ \\
\hline High School & 1.24 & $0.62,2.47$ \\
\hline University & 0.94 & $0.47,1.91$ \\
\hline Prenatal vitamins & 0.43 & $0.25,0.74$ \\
\hline Peak iAs $(\mu g / L)^{c, d}$ & 0.98 & $0.96,1.01$ \\
\hline Age & 1.05 & $1.00,1.10$ \\
\hline Smoking & 1.02 & $0.98,1.06$ \\
\hline High School & 1.23 & $0.62,2.46$ \\
\hline University & 0.96 & $0.47,1.93$ \\
\hline Prenatal vitamins & 0.43 & $0.25,0.74$ \\
\hline Daily iAs $(\mu \mathrm{g} / \text { day })^{c, e}$ & 1.00 & $0.98,1.02$ \\
\hline Age & 1.05 & $1.01,1.10$ \\
\hline Smoking & 1.02 & $0.98,1.06$ \\
\hline High School & 1.25 & $0.63,2.49$ \\
\hline University & 1.00 & $0.49,2.03$ \\
\hline Prenatal vitamins & 0.44 & $0.25,0.75$ \\
\hline
\end{tabular}

aLogistic regression models conditioned on gestational age (weeks) and adjusted for maternal age (years), cigarette smoking during pregnancy (average daily cigarettes), education (<High School, High School, University) and prenatal vitamin use (no/yes); ${ }^{\mathrm{b}}$ mean iAs level measured in up to two residential drinking water sources; $\mathrm{c} n=2$ influential observations excluded;

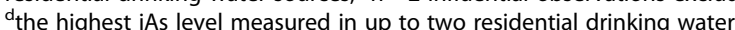
sources; 'product of 'daily water consumption' multiplied by 'average iAs.' iAs, inorganic arsenic; $\mathrm{Cl}$, confidence interval; OR, odds ratio.

estimates, expressed as ORs for a one unit increase in exposure, were close to 1.0 for arsenic exposure in all models, maternal age was consistently and significantly associated with increased odds for pregnancy loss, and prenatal vitamin use was consistently and significantly associated with decreased odds for loss. Results were similar when expressing exposure by tertiles, when excluding participants exposed to $>50 \mu \mathrm{g} / \mathrm{L}$ iAs on average and when adjusted for BMI (data not shown).

In interaction models, the association between iAs exposure and pregnancy loss was modified by cigarette smoking during pregnancy (Table 4). A $10 \mu \mathrm{g} / \mathrm{L}$ increase in average drinking water iAs corresponded to increased odds for loss in smokers, but a possible decrease among non-smokers. We generated analogous results using peak drinking water iAs or daily iAs as the exposure, although the latter was modest. The association between daily iAs exposure and loss was modified by prenatal vitamin use, in which a $10 \mu \mathrm{g}$ increase in daily iAs exposure corresponded to decreased odds for loss in users with no effect among non-users (Table 4). We did not detect interactions with average or peak drinking water iAs concentrations and prenatal vitamin use. Comparable results were produced by excluding participants exposed to $>50 \mu \mathrm{g} / \mathrm{L}$ iAs on average (data not shown). We found no evidence for effect modification by age, BMI, urban vs. rural residence, marital status, education or reproductive history (data not shown).

\section{Discussion}

In this hospital-based case-control study we report no statistically significant association between low-moderate level drinking water iAs contamination and spontaneous clinical pregnancy loss. After adjustment for confounders, effect estimates were close to the null for average and peak drinking water iAs concentrations, as well as for daily drinking water iAs exposure. Assessing interactions, we detected modest evidence for increased odds among cigarette smokers, as well as for decreased odds among prenatal vitamins users.

The detection of age as a risk factor and use of prenatal vitamins as a protective factor in our multivariable models are similar to the results reported by previous studies. Each additional maternal year increased the odds for pregnancy loss by approximately 1.05-1.06-fold, consistent with prior reports of increased risks among women in their early 20 s to early 40 s [31], and likely associated at least in part with increased rates of chromosomal aneuploidy [42]. Use of prenatal vitamins was associated with a 0.4-0.5-fold decrease in the odds for pregnancy loss, similar to the effects sizes previously reported for self-reported vitamin supplement use in early pregnancy [38]. A review of supplementation trials did not support a protective role, and thus self-reported prenatal vitamin use may reflect other protective healthrelated behaviors, rather than an effect of vitamins per se [43]. In contrast, we did not detect a previously reported odds increase in association with cigarette smoking [44]. Approximately $26.9 \%$ of Romanian women aged 15-45 years smoked a daily average of 14.1 cigarettes in 2011 [45], similar to our controls. Thus, the result may be a chance occurrence. A larger sample will allow for a definitive explanation.

Most previous investigations of drinking water exposure and spontaneous pregnancy loss were conducted in populations employing highly contaminated sources, generally $>50 \mu \mathrm{g} / \mathrm{L}$ iAs [5]. Two large ecologic studies reported increased rates of pregnancy loss among women residing in regions of Hungary [6] and Chile [7] with high level groundwater iAs contamination. A third reported a 1.16fold (95\% CI 0.001-1.34) increased risk for spontaneous abortion in Hungarian women using drinking water contaminated by $>20 \mu \mathrm{g} / \mathrm{L}$ compared to $<10 \mu \mathrm{g} / \mathrm{L}$ iAs [46]. Several small cross-sectional studies $(n=16$ to $n=192)$ conducted in Bangladesh and India [8-11,16] reported loss rates 1.6-fold to 3.3-fold higher for women employing 
Table 4 Covariate-adjusted odds ratios for spontaneous pregnancy loss in association with continuous iAs exposure, by cigarette smoking $(n=300)$

\begin{tabular}{|c|c|c|c|c|c|}
\hline \multirow[t]{2}{*}{ Product-term entered } & \multirow{2}{*}{$\begin{array}{l}\text { Risk/Protector } \\
\text { factor and iAs } \\
\text { exposure }\end{array}$} & \multicolumn{2}{|c|}{ Cigarette smoking $^{\mathrm{a}}$} & \multicolumn{2}{|c|}{ Prenatal vitamin use ${ }^{b}$} \\
\hline & & $\mathrm{OR}^{\mathrm{c}}$ & $95 \% \mathrm{Cl}$ & $\mathrm{OR}^{\mathrm{c}}$ & $95 \% \mathrm{Cl}$ \\
\hline \multirow[t]{7}{*}{ Average iAs $(\mu \mathrm{g} / L)^{d} \times$ Risk/Protector factor } & No & & & & \\
\hline & $0.0 \mu \mathrm{g} / \mathrm{L} \mathrm{iAs}$ & 1.00 & Reference & 1.00 & Reference \\
\hline & $10.0 \mu \mathrm{g} / \mathrm{L} \mathrm{iAs}$ & 0.70 & $0.44,1.09$ & 1.12 & $0.72,1.72$ \\
\hline & Yes & & & & \\
\hline & $0.0 \mu \mathrm{g} / \mathrm{L} \mathrm{iAs}$ & 0.97 & $0.51,1.83$ & 0.50 & $0.27,0.90$ \\
\hline & $10.0 \mu \mathrm{g} / \mathrm{L} \mathrm{iAs}$ & 1.75 & $0.75,4.10$ & 0.30 & $0.13,0.67$ \\
\hline & P-value for interaction & \multicolumn{2}{|c|}{0.057} & \multicolumn{2}{|c|}{0.159} \\
\hline \multirow[t]{7}{*}{ Peak iAs $(\mu \mathrm{g} / L)^{\mathrm{e}} \times$ Risk/Protector factor } & No & & & & \\
\hline & $0.0 \mu \mathrm{g} / \mathrm{LiAs}$ & 1.00 & Reference & 1.00 & Reference \\
\hline & $10.0 \mu \mathrm{g} / \mathrm{L} \mathrm{iAs}$ & 0.73 & $0.52,1.04$ & 1.07 & $0.71,1.63$ \\
\hline & Yes & & & & \\
\hline & $0.0 \mu \mathrm{g} / \mathrm{LiAs}$ & 0.97 & $0.51,1.82$ & 0.47 & $0.26,0.86$ \\
\hline & $10.0 \mu \mathrm{g} / \mathrm{L} \mathrm{iAs}$ & 1.69 & $0.76,3.74$ & 0.35 & $0.18,0.70$ \\
\hline & P-value for interaction & \multicolumn{2}{|c|}{0.053} & \multicolumn{2}{|c|}{0.298} \\
\hline \multirow[t]{7}{*}{ Daily iAs $(\mu \mathrm{g} / \text { day })^{f} \times$ Risk/Protector factor } & No & & & & \\
\hline & $0.0 \mu \mathrm{g} /$ day iAs & 1.00 & Reference & 1.00 & Reference \\
\hline & 10.0 mg/day iAs & 0.78 & $0.58,1.06$ & 1.04 & $0.80,1.34$ \\
\hline & Yes & & & & \\
\hline & $0.0 \mu \mathrm{g} /$ day iAs & 0.94 & $0.49,1.78$ & 0.54 & $0.30,0.98$ \\
\hline & 10.0 mg/day iAs & 1.41 & $0.73,2.74$ & 0.31 & $0.15,0.63$ \\
\hline & P-value for interaction & \multicolumn{2}{|c|}{0.048} & \multicolumn{2}{|c|}{0.085} \\
\hline
\end{tabular}

${ }^{a} \mathrm{n}=2$ influential observations excluded;

${ }^{b} \mathrm{n}=4$ influential observations excluded;

'Logistic regression models incorporating continuous exposure expressed as a 10 units increase, conditioned on gestational age (weeks), and including product-term, adjusted for maternal age (years), cigarette smoking during pregnancy (average daily cigarettes), education (<High School, High School, University)

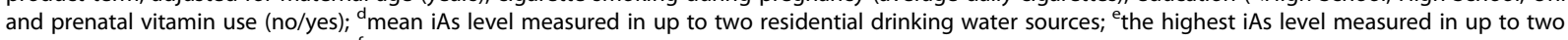
residential drinking water sources; f product of 'daily water consumption' multiplied by 'average iAs.'

iAs, inorganic arsenic; $\mathrm{Cl}$, confidence interval; OR, odds ratio.

drinking water sources contaminated by $50-1,474 \mu \mathrm{g} / \mathrm{L}$ iAs compared to $0-400 \mu \mathrm{g} / \mathrm{L}$ iAs. In larger cross-sectional studies, a 1.75 -fold increase in the rate of loss $(\mathrm{P}<0.05)$ was reported for 300 Bengali women exposed to 10$600 \mu \mathrm{g} / \mathrm{L}$ iAs [18] and a 2.7 -fold increase in the rate of loss (95\% CI 0.8-8.40) was reported for 323 Mongolian women exposed to $>50 \mu \mathrm{g} / \mathrm{L}$ iAs [19]. Similar pregnancy loss rates were reported for women exposed to $>200 \mu \mathrm{g} / \mathrm{L}$ iAs compared to $<50 \mu \mathrm{g} / \mathrm{L}$ iAs in a cross-sectional study of 587 West Bengal pregnancies [17]. A prospective study of 29,134 Bangladeshi women reported a 1.14fold increased risk (95\% CI 1.04-1.25) for all spontaneous and induced pregnancy losses among women exposed to $>50 \mu \mathrm{g} / \mathrm{L}$ iAs [13]. The same group of investigators more recently reported a 1.4 -fold risk increase $(95 \%$ CI 0.96-2.2) for spontaneous loss before 28 weeks completed gestation in the highest compared to the lowest quintiles of urine total iAs, yet without evidence for a doseresponse relation [15].
To our knowledge, only one previously published study assessed spontaneous pregnancy loss in a population exposed primarily to drinking water sources contaminated by $<10 \mu \mathrm{g} / \mathrm{L}$ iAs. In that 1976-1978 hospital-based U.S. case-control study [22], increased odds for spontaneous loss was reported in association with exposure to municipal drinking water contaminated by $0.8-1.3 \mu \mathrm{g} / \mathrm{L}$ iAs (OR 1.2, 95\% CI 1.0-1.6), or 1.4-1.9 $\mu \mathrm{g} / \mathrm{L}$ iAs (OR 1.7 95\% CI $0.7-4.2)$ compared to $<0.8 \mu \mathrm{g} / \mathrm{L}$ iAs. The use of routinely water quality data reports was likely to have introduced non-differential exposure measurement misclassification, and so the results may have been biased towards the null hypothesis. Our work expands upon this only study of low-level drinking water exposures, as half of our participants were exposed to an average of less than $0.41 \mu \mathrm{g} / \mathrm{L}$ iAs and most were exposed to less than $9.39 \mu \mathrm{g} / \mathrm{L}$ iAs on average. However, point estimates were fairly precise and close to the null hypothesis, indicating no likely increased risk. 
The odds increase for pregnancy loss in association with drinking water iAs exposure was limited to cigarette smokers during pregnancy in this study, whereas there was a suggested protective iAs effect among non-smokers. However subgroup numbers were small, the effect estimates imprecise and the latter unexpected association contradicted our initial hypothesis. Furthermore, ours is the first report of iAs associated adverse pregnancy effects among only smokers and so may reflect a chance occurrence. Still, an arsenic associated increased bladder cancer risk was also reported for smokers only in an American study [47]. Arsenic induced increases in the levels of reactive oxygen species (ROS) have been documented by experimental [48] and observational studies [49]. Excess ROS produces oxidative stress (OS), inducing lipid peroxidation, oxidizing proteins and nucleic acids, and leading to abnormal function and DNA lesions [50]. Glutathione serves a critical role in moderating OS [51] and is also an important factor for iAs metabolism [52]. Observational evidence indicates reduced levels of circulating glutathione among women with long-term exposure to iAs $>10 \mu \mathrm{g} / \mathrm{L}$ [53], and similar observations have been made for cigarette smokers [54]. Cigarette smokers might be more susceptible than non-smokers to toxic effects from lowdose arsenic exposure. In contrast, there was a suggestion for a possible protective effect for iAs exposure among women using prenatal vitamins, although the interaction was of borderline statistical significance, and was not detected using average or peak water iAs concentrations. Thus, this result may also reflect a chance occurrence.

Concentrations of iAs measured among sources used by study participants were lower than we had anticipated $a$ priori based on levels previously reported by Timis County authorities. A median of $4.96 \mu \mathrm{g} / \mathrm{L}$ iAs (range 0.01-71.66) was reported for 96 western Timis County drinking water sources sampled during 2005-2006 (Unpublished data). While these levels were greater than for the current study on average, it is important to note that only groundwater sources (i.e., wells) were captured in the Timis County Health Department survey and our current study collected samples from drinking water sources supplied by both surface and groundwater. The limited variability of exposures likely resulted from usage of municipal surface water sources low in iAs, with overall concentrations possibly below the threshold for an effect. In fact, when limited to only groundwater well samples, we measured a median of $3.61 \mu \mathrm{g} / \mathrm{L}$ iAs (range 0.00-175.10) in 119 participants. Significant loss increases have been reported only with $>20 \mu \mathrm{g} / \mathrm{L}$ iAs [46]. Urine iAs biomarkers will be necessary to fully assess the impact. Our study population comprised clinically recognized pregnancies which also may have shifted the exposures towards lower values if iAs reduced pregnancy, a hypothesis we intend to explore in a separate manuscript.
Several issues limit the results of our pilot study. We captured only clinically-recognized pregnancy losses, which might have introduced a competing-risk bias towards the null hypothesis should pre-clinical loss be associated with iAs exposure [55]; thus, true effects may be even greater than we report here. A large number of pregnancy losses are induced in our study population; $71 \%$ of the abortions treated in Timis County (i.e., Bega Hospital) were elective during 2008 [56]. Elective terminations were excluded from our study, yet we do not suspect differential exposure between women with induced and spontaneous losses and so bias is unlikely. We also did not accommodate exposure to other potential causes of pregnancy loss that may 'track' with iAs. Variable exceedances of European Union (EU) air quality standards for $\mathrm{CO}$ and $\mathrm{NO}_{\mathrm{x}}$ occurred within limited areas of Timisoara during 2008 [57]. However, the evidence for associations with spontaneous loss is weak, and purported associations are low [58]. Furthermore, we identified no associations using 'urban residence' as a proxy for air pollution exposure. We also did not incorporate assessment of iAs metabolism, which may have introduced a bias towards the null hypothesis. Wide between-person variability is reported for iAs detoxification, governed by genetic polymorphisms [59] and nutritional factors [52]. Likewise, our use of self-reported health-behaviors data including cigarette smoking, alcohol consumption and prenatal vitamin use may have introduced misclassification, but the nature of any misreport is difficult to predict. Finally, reproduction is a couple-level function [60] although we captured only maternal data. We believe maternal exposures are likely to be of greater importance, but evidence also suggests the relevance of male factors to pregnancy loss $[61,62]$.

\section{Conclusions}

In conclusion, our study results indicate no increased risk for spontaneous pregnancy loss of $<20$ weeks completed gestation among women with low to moderate drinking water iAs exposure. Prenatal vitamin use appeared to be protective. While our results are internally valid, we recommend caution in generalizing to other populations and to groups with dissimilar levels of iAs exposure, dietary habits and health-related behaviors. Given the low overall exposures our study should reassure mothers, clinicians and policy makers in Timis County. Still, our data raise the possibility for an increased risk among women smoking cigarettes during pregnancy, which merits a more definitive investigation. These results add to our knowledge as to how low-levels of iAs impact human reproduction.

\section{Abbreviations}

iAs: Inorganic arsenic; BMI: Body mass index; Cl: Confidence interval; $\delta$ : Difference; OR: Odds ratio; OS: Oxidative stress; ROS: Reactive oxygen species. 


\section{Competing interests}

The authors declare they have no competing interests.

\section{Authors' contributions}

MSB, IAN, DA, EFS and ESG conceived and designed the study; IAN and DA recruited study participants and collected data; IAN, IRL and ESG collected drinking water samples; CP and ESG conducted the drinking water arsenic analysis; MSB and SS conducted the data analysis; MSB drafted the initial manuscript; all authors revised the manuscript for critical intellectual content and read and approved the final version for submission.

\section{Acknowledgements}

This work was supported by Grant \#R03ES020446 from the National Institute of Environmental Health Sciences (NIEHS). The content is solely the responsibility of the authors and does not necessarily represent the official views of the NIEHS or the NIH. The NIEHS played no role in the study design; in the collection, analysis and interpretation of data; in the writing of the report; or in the decision to submit this article for publication. We would like to thank Dr. Ramona C. Anculia, Ms. Liliana Grigore and Ms. Ioana Trofin for their tireless efforts in recruiting study participants, conducting interviews and collecting and processing biospecimens. We would also like to thank the participants, whose generous time and effort made this study possible.

\section{Author details}

${ }^{1}$ Department of Environmental Health Sciences, University at Albany, State University of New York, School of Public Health, Rensselaer, NY, USA. ${ }^{2}$ Department of Epidemiology and Biostatistics, University at Albany, State University of New York, School of Public Health, Rensselaer, NY, USA. ${ }^{3}$ Environmental Health Center, Cluj-Napoca, Romania. ${ }^{4}$ University of Medicine and Pharmacy "Victor Babes", Timisoara, Romania. ${ }^{5}$ Obstetrics and Gynecology Department of the Emergency County Hospital, Timisoara, Romania. 'University of Medicine and Pharmacy "Iuliu Hațieganu", Cluj-Napoca, Romania.

\section{Received: 28 July 2014 Accepted: 6 October 2014}

Published: 13 October 2014

\section{References}

1. WHO: Some Drinking-Water Disinfectants and Contaminants, Including Arsenic. In IARC Monographs on the Evaluation of Carcinogenic Risks to Humans / World Health Organization, International Agency for Research on Cancer. vol. 84th edition. Edited by World Health Organization. Geneva, Switzerland: World Health Organization (WHO); 2004:477.

2. Smedley PL, Kinniburgh DG: A review of the source, behaviour and distribution of arsenic in natural waters. Appl Geochem 2002, 17:517-568.

3. van Halem D, Bakker SA, Amy GL, van Dijk JC: Arsenic in drinking water: a worldwide water quality concern for water supply companies. DWES 2009, 2:29-34

4. ATSDR: Toxicological Profile for Arsenic. Atlanta, GA: U.S. Agency for Toxic Substances and Disease Registry; 2007:499.

5. Bloom MS, Fitzgerald EF, Kim K, Neamtiu I, Gurzau ES: Spontaneous pregnancy loss in humans and exposure to arsenic in drinking water. Int J Hyg Environ Health 2010, 213:401-413.

6. Borzsonyi M, Bereczky A, Rudnai P, Csanady M, Horvath A: Epidemiological studies on human subjects exposed to arsenic in drinking water in southeast Hungary. Arch Toxicol 1992, 66:77-78.

7. Hopenhayn-Rich C, Browning SR, Hertz-Picciotto I, Ferreccio C, Peralta C, Gibb H: Chronic arsenic exposure and risk of infant mortality in two areas of Chile. Environ Health Perspect 2000, 108:667-673.

8. Chakraborti D, Sengupta MK, Rahman MM, Ahamed S, Chowdhury UK, Hossain MA, Mukherjee SC, Pati S, Saha KC, Dutta RN, Quamruzzaman Q: Groundwater arsenic contamination and its health effects in the Ganga-Meghna-Brahmaputra plain. J Environ Monit 2004, 6:74N-83N

9. Ahmad SA, Salim Ullah Sayed MH, Barua S, Haque Khan M, Faruquee MH, Jalil A, Abdul Hadi S, Kabir Talukder H: Arsenic in drinking water and pregnancy outcomes. Environ Health Perspect 2001, 109:629-631.

10. Mukherjee SC, Saha KC, Pati S, Dutta RN, Rahman MM, Sengupta MK, Ahamed S, Lodh D, Das B, Hossain M, Nayak B, Mukherjee A, Chakraborti D, Dulta SK, Palit SK, Kaies I, Barua AK, Asad KA: Murshidabad - One of the nine groundwater arsenic-affected districts of West Bengal, India. Part II: dermatological, neurological, and obstetric findings. Clin Toxicol 2005, 43:835-848

11. Ahamed S, Sengupta MK, Mukherjee SC, Pati S, Mukherjee A, Rahman MM, Hossain MA, Das B, Nayak B, Pal A, Zafar A, Kabir S, Banu SA, Morshed S, Islam T, Quamruzzaman Q, Chakraborti D: An eight-year study report on arsenic contamination in groundwater and health effects in Eruani Village, Bangladesh and an approach for its mitigation. $J$ Health Popul Nutr 2006, 24:129-141.

12. Cherry N, Shaikh K, McDonald C, Chowdhury Z: Stillbirth in rural Bangladesh: arsenic exposure and other etiological factors: a report from Gonoshasthaya Kendra. Bull World Health Organ 2008, 86:172-177.

13. Rahman A, Vahter M, Ekstrom E-C, Rahman M, Golam Mustafa AHM, Wahed MA, Yunus M, Persson L-A: Association of arsenic exposure during pregnancy with fetal loss and infant death: a cohort study in Bangladesh. Am J Epidemiol 2007, 165:1389-1396.

14. Kwok RK, Kaufmann RB, Jakariya M: Arsenic in drinking-water and reproductive health outcomes: a study of participants in the Bangladesh integrated nutrition programme. J Health Popul Nutr 2006, 24:190-205.

15. Rahman A, Persson L-A, Nermell B, El Arifeen S, Ekstrom E-C, Smith AH, Vahter M: Arsenic exposure and risk of spontaneous abortion, stillbirth, and infant mortality. Epidemiology 2010, 21:797-804.

16. Chakraborti D, Mukherjee SC, Pati S, Sengupta MK, Rahman MM, Chowdhury UK, Lodh D, Chanda CR, Chakraborti AK, Basu GK: Arsenic groundwater contamination in Middle Ganga Plain, Bihar, India: a future danger? Environ Health Perspect 2003, 111:1194-1201.

17. von Ehrenstein OS, Guha Mazumder DN, Hira-Smith M, Ghosh N, Yuan Y, Windham G, Ghosh A, Haque R, Lahiri S, Kalman D, Das S, Smith AH: Pregnancy outcomes, infant mortality, and arsenic in drinking water in West Bengal. India Am J Epidemiol 2006, 163:662-669.

18. Sen J, Chaudhuri ABD: Arsenic exposure through drinking water and its effect on pregnancy outcome in Bengali women. Arh Hig Rada Toksikol 2008, 59:271-275.

19. Guo X, Fujino Y, Chai J, Wu K, Xia Y, Li Y, Lv J, Sun Z, Yoshimura T: The prevalence of subjective symptoms after exposure to arsenic in drinking water in Inner Mongolia. China J Epidemiol 2003, 13:211-215.

20. Mead MN: Arsenic: in search of an antidote to a global poison. Environ Health Perspect 2005, 113:A378-A386.

21. Ayotte JD, Gronberg JM, Apodaca LE: Trace Elements and Radon in Groundwater Across The United States: U.S. Geological Survey Scientific Investigations Report 2011-5059. 2011:115.

22. Aschengrau A, Zierler S, Cohen A: Quality of community drinking water and the occurrence of spontaneous abortion. Arch Environ Health 1989, 44:283-290.

23. Miller JF, Williamson E, Glue J: Fetal loss after implantation. A prospective study. Lancet 1980, 2:554-556.

24. Wilcox AJ, Weinberg CR, O'Connor JF, Baird DD, Schlatterer JP, Canfield RE, Armstrong EG, Nisula BC: Incidence of early loss of pregnancy. N Engl J Med 1988, 319:189-194.

25. Rowland HAL, Omoregie EO, Millot R, Jimenez C, Mertens J, Baciu C, Hug SJ, Berg M: Geochemistry and arsenic behaviour in groundwater resources of the Pannonian Basin (Hungary and Romania). Appl Geochem 2011, 26:1-17.

26. Bloom MS, Buck Louis GM, Sundaram R, Kostyniak PJ, Jain J: Associations between blood metals and fecundity among women residing in New York State. Reprod Toxicol 2011, 31:158-163.

27. Hough RL, Fletcher T, Leonardi GS, Goessler W, Gnagnarella P, Clemens F, Gurzau E, Koppova K, Rudnai P, Kumar R, Vahter M: Lifetime exposure to arsenic in residential drinking water in Central Europe. Int Arch Occup Environ Health 2010, 83:471-481.

28. Schisterman EF, Vexler A, Whitcomb BW, Liu A: The limitations due to exposure detection limits for regression models. Am J Epidemiol 2006, 163:374-383.

29. Greenland S, Pearl J, Robins JM: Causal diagrams for epidemiologic research. Epidemiology 1999, 10:37-48.

30. Vahter M, Akesson A, Liden C, Ceccatelli S, Berglund M: Gender differences in the disposition and toxicity of metals. Environ Res 2007, 104:85-95.

31. Andersen AM, Wohlfahrt J, Christens P, Olsen J, Melbye M: Maternal age and fetal loss: population based register linkage study. Br Med J 2000, 320:1708-1712.

32. Centeno JA, Tseng CH, Van Der Voet GB, Finkelman RB: Global impacts of geogenic arsenic: a medical geology research case. Ambio 2007, 36:78-81. 
33. Ness RB, Grisso JA, Hirschinger N, Markovic N, Shaw LM, Day NL, Kline J: Cocaine and tobacco use and the risk of spontaneous abortion. N Engl J Med 1999, 340:333-339.

34. Macours K, Swinnen JFM: Rural-urban poverty differences in transition countries. World Dev 2008, 36:2170-2187.

35. Price SK: Prevalence and correlates of pregnancy loss history in a national sample of children and families. Matern Child Healt J 2006, 10:489-500.

36. Surdu S, Rudnai P, Gurzau A, Bodor E, Dora C, Gurzau ES, Fletcher T, Leonardi G: Natural Arsenic In Drinking Water And Adverse Health Effects In Romania. In Proceedings of the International Symposium on Environmental Epidemiology in Central and Eastern Europe: Critical Issues for Improving Health: 1997; Smolenice, Slovakia. 1997:43-46.

37. Heck JE, Gamble MV, Chen Y, Graziano JH, Slavkovich V, Parvez F, Baron JA Howe GR, Ahsan $\mathrm{H}$ : Consumption of folate-related nutrients and metabolism of arsenic in Bangladesh. Am J Clin Nutr 2007, 85:1367-1374.

38. Hasan R, Olshan AF, Herring AH, Savitz DA, Siega-Riz AM, Hartmann KE: Self-reported vitamin supplementation in early pregnancy and risk of miscarriage. Am J Epidemiol 2009, 169:1312-1318.

39. Knol MJ, Egger M, Scott P, Geerlings MI, Vandenbroucke JP: When one depends on the other: reporting of interaction in case-control and cohort studies. Epidemiology 2009, 20:161-166.

40. Kleinbaum DG, Kupper LL, Muller KE, Nizam A: Regression Diagnostics. In Applied Regression Analysis and Other Multivariable Methods. Edited by Kleinbaum DG, Kupper LL, Muller KE, Nizham A. Pacific Grove, CA: Duxbury Press; 1998:212-280.

41. Greenland S, Thomas DC: On the need for the rare disease assumption in case-control studies. Am J Epidemiol 1982, 116:547-555.

42. Pellestor F, Andréo B, Anahory T, Hamamah S: The occurrence of aneuploidy in human: lessons from the cytogenetic studies of human oocytes. Eur J Med Genet 2006, 49:103-116.

43. Rumbold A, Middleton P, Pan N, Crowther CA: Vitamin supplementation for preventing miscarriage. Cochrane Database Syst Rev 2011, 1:191

44. Hughes EG, Brennan BG: Does cigarette smoking impair natural or assisted fecundity? Fertil Steril 1996, 66:679-689.

45. Ministry of Health Romania, World Health Organization - Regional Office for Europe: Romania 2011: Global Adult Tobacco Survey. Cluj-Napoca, Romania: Ministry of Health Romania; 2012:140.

46. Rudnai $P$, Csanady M, Borsanyi M, Kadar M: Arsenic in Drinking Water and Pregnancy Outcomes: An Overview Of The Hungarian Findings (19852005). In Arsenic: Sources, Environmental Impact, Toxicity and Human Health A Medical Geology. Edited by Masotti A. Happauge, NY: Nova; 2013:173-180.

47. Karagas MR, Tosteson TD, Morris JS, Demidenko E, Mott LA, Heaney J, Schned A: Incidence of transitional cell carcinoma of the bladder and arsenic exposure in New Hampshire. Cancer Causes Control 2004, 15:465-472.

48. Flora SJS: Arsenic-induced oxidative stress and its reversibility. Free Radic Biol Med 2011, 51:257-281

49. Banerjee N, Banerjee M, Ganguly S, Bandyopadhyay S, Das JK, Bandyopadhay A, Chatterjee M, Giri AK: Arsenic-induced mitochondrial instability leading to programmed cell death in the exposed individuals. Toxicology 2008, 246:101-111.

50. Gupta S, Agarwal A, Banerjee J, Alvarez JG: The role of oxidative stress in spontaneous abortion and recurrent pregnancy loss: a systematic review. Obstet Gynecol Surv 2007, 62:335-347.

51. Ercal N, Gurer-Orhan H, Aykin-Burns N: Toxic metals and oxidative stress part I: mechanisms involved in metal-induced oxidative damage. Curr Top Med Chem 2001, 1:529-539.

52. Vahter M: Mechanisms of arsenic biotransformation. Toxicology 2002 181-182:211-217

53. Hall MN, Niedzwiecki M, Liu X, Harper KN, Alam S, Slavkovich V, Ilievski V, Levy D, Siddique AB, Parvez F, Mey JL, van Geen A, Graziano J, Gamble MV Chronic arsenic exposure and blood glutathione and glutathione disulfide concentrations in Bangladeshi adults. Environ Health Perspect 2013, 121:1068-1074.

54. Moriarty SE, Shah JH, Lynn M, Jiang S, Openo K, Jones DP, Sternberg P Jr: Oxidation of glutathione and cysteine in human plasma associated with smoking. Free Radic Biol Med 2003, 35:1582-1588.

55. Olsen J, Skov T: Design options and methodological fallacies in the studies of reproductive failures. Environ Health Perspect 1993, 101:145-152.
56. Department of Statistics, Timis [http://www.timis.insse.ro/cmstimis/rw/ pages/index.ro.do] Accessed: April 4th, 2011

57. Popescu F, lonel I, Lontis N, Calin L, Dungan IL: Air quality monitoring in an urban aglomeration. Rom J Phys 2011, 56:495-506.

58. Polichetti G, Capone D, Grigoropoulos K, Tarantino G, Nunziata A, Gentile A: Effects of ambient air pollution on birth outcomes: an overview. Crit Rev Environ Sci Technol 2013, 43:1223-1245.

59. Lindberg AL, Kumar R, Goessler W, Thirumaran R, Gurzau E, Koppova K, Rudnai $P$, Leonardi G, Fletcher T, Vahter M: Metabolism of low-dose inorganic arsenic in a Central European population: influence of sex and genetic polymorphisms. Environ Health Perspect 2007, 115:1081-1086

60. Joffe M: Infertility and environmental pollutants. Br Med Bull 2003, 68:47-70

61. Zini A, Boman JM, Belzile E, Ciampi A: Sperm DNA damage is associated with an increased risk of pregnancy loss after IVF and ICSI: systematic review and meta-analysis. Hum Reprod 2008, 23:2663-2668.

62. Slama R, Bouyer J, Windham G, Fenster L, Werwatz A, Swan SH: Influence of paternal age on the risk of spontaneous abortion. Am J Epidemiol 2005, 161:816-823.

doi:10.1186/1476-069X-13-81

Cite this article as: Bloom et al: Consumption of low-moderate level arsenic contaminated water does not increase spontaneous pregnancy loss: a case control study. Environmental Health 2014 13:81.

\section{Submit your next manuscript to BioMed Central and take full advantage of:}

- Convenient online submission

- Thorough peer review

- No space constraints or color figure charges

- Immediate publication on acceptance

- Inclusion in PubMed, CAS, Scopus and Google Scholar

- Research which is freely available for redistribution 